\title{
Preface
}

\section{Why This Book?}

Finding shelter is one of the most primal human needs, right alongside food and water. But we are long past the time when shelter was a place to return to after a day of foraging - when it meant a roof over our heads and not much more. In that long-gone era, we spent all of our time outdoors. Today, these "shelters" are the places where we live, work, learn, play, rest, and recuperate. Over several millennia, humans have evolved from an outdoor species into an indoor one.

Yet despite the fact that buildings are now central to our lives and livelihoods, the quality of the air we breathe inside them is generally an afterthought. Have you ever seen a news story about outdoor air pollution? Yes, of course. Every day. Have you ever read a story about indoor air pollution? Rarely, if ever. We spend a great deal of our time worrying about outdoor pollution, yet it's the indoor environment that has the greatest impact on our health.

Most buildings today have been designed to optimize specific functions. Their "health worthiness" is defined by a variety of building codes: there are standards for sanitation, electrical wiring, fireproofing, lighting and ventilation, access, and many other things. A quick glance at the history of urban form suggests that aesthetics, comfort, and grandeur are important to us as well.

At some level we all know that indoor environments influence how we feel and perform because every one of us has experienced a poor-performing indoor space, be it a stuffy conference room or a friend's house that makes you sneeze as soon as you walk in the door. There are office buildings that give you an immediate and visceral reaction- "THIs is a place I want to work," or "Get me out of here." What has been elusive is piecing it all together. 
We have good news to share: there are easy ways to make a building "healthy." Even better, Healthy Building strategies are good business strategies. Because it turns out that the true cost of operating our buildings is not energy, waste, and water (the drivers of the "green" building movement); it's the people inside. So when we make our buildings healthy, we make the people in those buildings healthier and more productive, and that translates into a healthier bottom line.

This convergence of health science, building science, and business science is revealing what is perhaps the greatest untapped business and health opportunity of our time.

As the green building movement transitions to the Healthy Building movement, savvy business leaders can capitalize on this once-in-a-lifetime opportunity by tapping into the science underpinning these three previously siloed disciplines. As you will soon see, it turns out that Healthy Building strategies are a win-win value proposition for all stakeholders: business leaders, workers, investors and developers, and the public.

For business leaders: You know better than anyone that you are in a global competition for talent. What you may not recognize is that you can use your building to attract and retain the best and the brightest. And then, once your organization has invested so much in attracting talent, you can manage your building to optimize the performance of that talent. This book reveals the secret to capturing the value locked up in your building's most important and expensive asset: the people you hire. Are you using your building as a Human Resources tool?

For workers: Prospective employees ask questions about the nature of their responsibilities, their boss, their salary, and how much vacation time they will get. Now it's time to ask questions about the one thing that will have the biggest impact on your health and performance: the place where you will be working. What are your building managers doing to optimize your indoor environment? Are they tracking indicators of environmental quality and taking corrective action when something is "off"? Are they simply meeting minimum performance requirements, or are they adopting strategies that promote your well-being? Are you interviewing your building? 
For investors and developers: The green building movement is giving way to the Healthy Building movement, and for good reason. The green building movement was largely built chasing monetary savings from energy savings. By one estimate, over $\$ 7$ trillion in real estate institutional capital tracks the performance of green buildings. Yet this investment was driven by chasing 1 percent of the cost to operate our buildings-energy, waste, and water. But we don't build buildings to save energy; we build them for people. Is your investment future-proofed for the coming Healthy Buildings movement?

For all of us on this planet: Buildings affect our health through their intimate relationships with our energy system and the changing climate. Global energy production is dominated by fossil fuel use, and buildings consume 40 percent of that energy. In some places, like New York City, it's close to 80 percent. Energy-saving features in buildings therefore come with a health co-benefit in terms of reduced emissions of air pollution and greenhouse gases. Does your building come with a public health benefit?

In this book we bring together 40 years of health science, building science, and business science to explain why buildings matter so much for our health and wealth. The three disciplines have been historically treated as separate, but they are in fact inextricably linked. We provide the hard, scientific evidence to make the business case for Healthy Buildings, while showing in practical terms how buildings can be used to create this win-win value proposition for owners, occupants, developers, and society. In this book we will show you exactly how you can unlock this value proposition by providing answers to questions that the market is asking:

What is a Healthy Building, anyway? How do Healthy Building strategies affect the performance of my company? What is driving this movement? How will smart buildings intersect with Healthy Buildings? How do we create and capture value by mapping investments to benefits? Can we scale this globally?

These are just a few of the questions we will tackle as we show you how to unlock the potential of your buildings to create economic value and improve human health and performance. 
